\title{
Tectonic evolution of the Engi Slates, Glarus Alps, Switzerland
}

\author{
Deta GASSER ${ }^{1,2}$ \& BAS DEN BROK ${ }^{1,3}$
}

Key words: Engi Slates, Glarus Alps, infrahelvetic complex, North Helvetic Flysch

\begin{abstract}
We present a geological map, profiles and the results of a detailed structural analysis of the Early Oligocene Engi Slates southwest of the village of Engi in the Sernft Valley in canton Glarus (Switzerland). In this area, the Engi Slates are folded on a deca- to hectometer scale into tight NW-vergent folds with sharp hinges. This took place during the Plattenberg $F_{1}$ folding phase. No axial plane foliation was formed. The $\mathrm{F}_{1}$ folds are unconformably cut-off by a $16-25^{\circ} \mathrm{NE}$ dipping thrust, along which Eocene marls were emplaced onto the folded Engi Slates. We refer to this thrust as Riedboden Thrust and correlate it with
\end{abstract}

the base of the upper, chaotic part of the Wildflysch Nappe of Oberholzer (1942). This is a (probably tectonic) mélange of rocks from the underlying Sardona, Blattengrat and North Helvetic Flysch Units. It lies as a 5 to $100 \mathrm{~m}$ thick, more or less continuous nappe below the Glarus Thrust. A younger, SE-dipping tectonic foliation (Plattenberg $\mathrm{F}_{2}$ foliation) cuts both through the folded Engi Slates, the Riedboden Thrust and the Eocene marls. This foliation is the axial plane foliation to meter-scale open $\mathrm{F}_{2}$ folds. It developed parallel to the overturned limbs of the $\mathrm{F}_{1}$-folds.

\section{Introduction}

The Early Oligocene Engi Slates in the Glarus Alps are famous for their fossil record. Thousands of beautifully preserved fishes, turtles and birds were collected during centuries of mining in the Engi slate mine (the „Landesplattenberg“; Wettstein 1886, Furrer and Leu 1998). These fossils are show-pieces of renowned paleontological collections, such as in the Paleontological Museum in Zürich and the Museum of Natural History in Basel. The slate mine is abandoned, but can be visited. There are guided tours through the mine shafts and a small museum next to the mine is dedicated to the mining history and regional geology.

Remarkably enough, a detailed geological map and profile through the Engi Slates is lacking. We therefore decided to geologically map the area at a scale 1:5,000 and to carry out a detailed structural analysis (Gasser 2006). The results are presented in this paper.

\section{Geological setting}

The Engi Slates crop out in the northern Sernft Valley between the villages Engi and Matt (Fig.1). They are part of the North Helvetic Flysch (NHF) Unit, which mainly consists of turbiditic sandstones and slates. Siegenthaler (1974) subdivided the NHF of the Sernft Valley into three formations. These are from bottom to top: (i) the Taveyannaz Formation, consisting of volcano-clastic, dark-greenish turbiditic sandstones, (ii) the Elm Formation, consisting of dark-grey turbiditic sandstones and slates, and (iii) the Matt Formation, consisting of (a) a lower member of light-grey turbiditic sandstones (the Matt Sandstones) and (b) an upper member of dark slates (the Engi Slates). Fossil fishes in the Engi Slates were dated Early Oligocene by Wettstein (1886). Andesitic hornblende from the Taveyannaz Formation has a K/Ar-radiometric age of $31.7 \pm 1.6$ and $32.4 \pm 1.6 \mathrm{Ma}$, and a ${ }^{40} \mathrm{Ar} /{ }^{39} \mathrm{Ar}$-radiometric age of $31.96 \pm 0.9 \mathrm{Ma}$ (Fischer \& Villa 1990), suggesting an Early Oligocene depositional age for these sediments as well.

\footnotetext{
${ }^{1}$ Geological Institute, ETH Central Campus, Universitätsstrasse 6, 8092 Zürich, Switzerland.

${ }^{2}$ Present address: Department for Earth Sciences, Universitätsplatz 2, 8010 Graz, Austria.

${ }^{3}$ Present address: Swiss Federal Institute of Aquatic Science and Technology (Eawag), Überlandstrasse 133,8600 Dübendorf, Switzerland.

Corresponding author: D. Gasser. E-mail: deta.gasser@uni-graz.at
} 
The NHF Unit is overthrust by the Blattengrat and Sardona Nappes. The Blattengrat Nappe consists of Late Cretaceous marls and Eocene limestones and marls (Bisig 1957, Trümpy 1969, Lihou 1995). The Sardona Nappe consists of Late Cretaceous limestones and marls, and an Eocene sequence of marine (mainly turbiditic) sandstones and marls (Leupold 1942, Trümpy 1969, Lihou 1996b). The NHF Unit, the Blattengrat Nappe and the Sardona Nappe were overthrust by Subhelvetic Units and by the Helvetic Nappes along the Glarus Thrust (Trümpy 1969, Schmid 1975), and are therefore commonly referred to as Infrahelvetic Complex (Milnes \& Pfiffner 1977, Pfiffner 1978; Fig. 1).

According to Schmid (1975), deformation within the Infrahelvetic Complex occurred in three phases. He named them phase 1, 2 and 3, respectively. During phase 1 the Sardona and Blattengrat Nappes slid onto the NHF foreland (possibly by gravity sliding). During phase 2 the Infrahelvetic Complex was

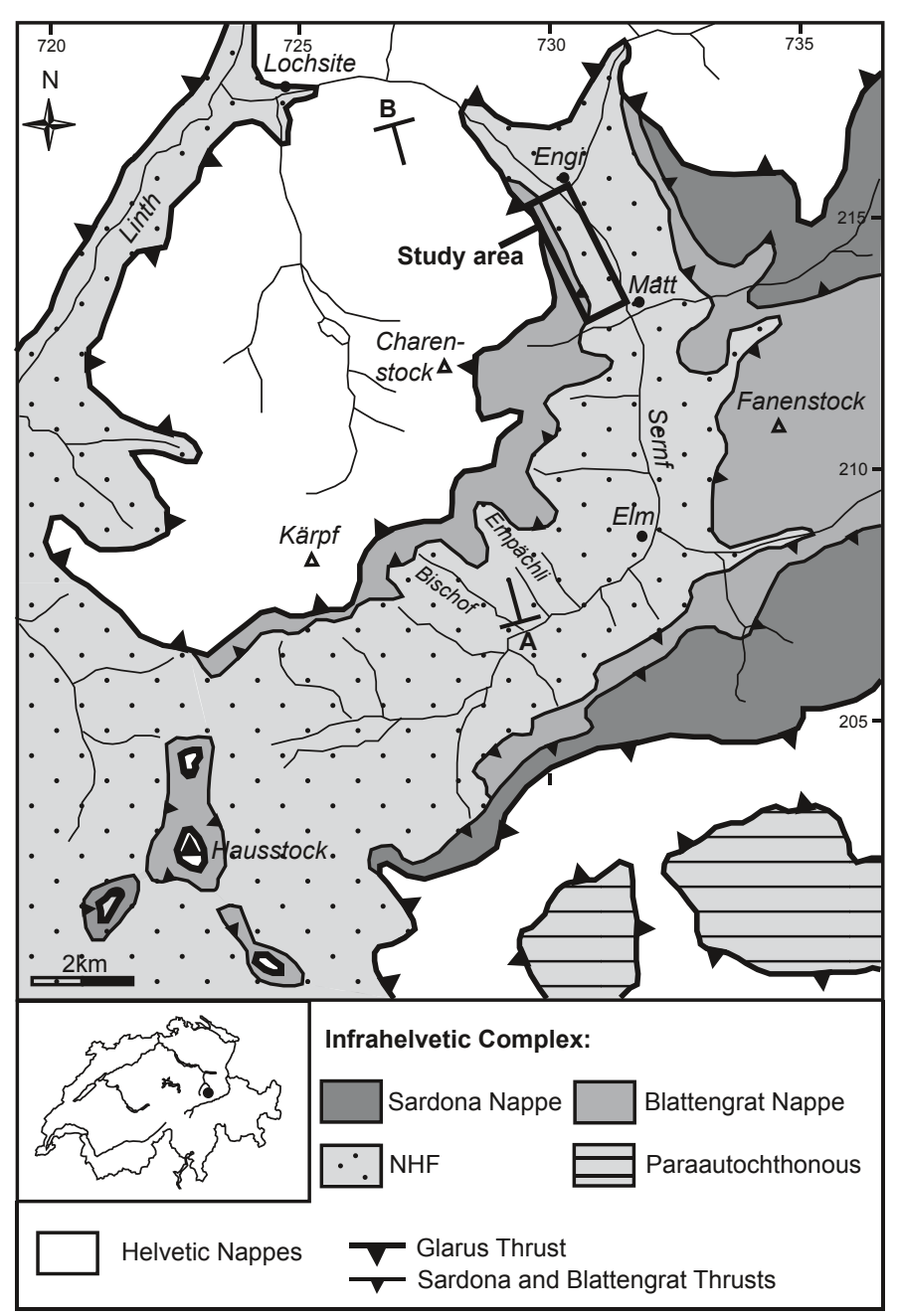

Fig. 1. Tectonic map of the Infrahelvetic Complex in the Sernft Valley (after Lihou 1996a). A-B: Profile trace of Figure 2. Coordinates in Swiss National Grid. folded and a penetrative axial plane cleavage developed. During phase 3 the Glarus Thrust developed - out of sequence. A minimum displacement of $35 \mathrm{~km}$ took place, during which a steep crenulation cleavage developed just below the thrust.

According to Milnes \& Pfiffner (1977; see also Pfiffner 1978, 1986, Lihou 1996a), deformation of the Infrahelvetic Complex occurred in four phases: (i) the Pizol phase, (ii) the Cavestrau phase (of local importance and not included in the present discussion), (iii) the Calanda phase, and (iv) the Ruchi phase, respectively. During the Pizol phase, the Sardona and Blattengrat Nappes were thrust onto the NHF Unit, not by gravity, but by compressional tectonics. Much of the chaotic folding within the Blattengrat and Sardona Nappes, and some of the folding and thrusting in the NHF Unit may have been initiated at this time as well. During the subsequent Calanda phase the Glarus Thrust developed along which $25-30 \mathrm{~km}$ displacement took place. At the same time the Infrahelvetic Complex was folded, and a penetrative axial plane cleavage developed. During the Ruchi phase, the Infrahelvetic Complex was further overthrust by the Helvetic Nappes by $5-10 \mathrm{~km}$ and a steep crenulation cleavage developed below the Glarus Thrust.

\section{Field results}

We mapped the area around Landesplattenberg Engi at the scale 1:5,000 and conducted detailed microstructural work on thin sections (Gasser 2006). The study area covers the Engi Slates on the western side of the Sernft Valley between Schwarzkopfrus in the south and Badchopfrus in the north (Fig. 2). Our geological map and two profiles through the study area are presented in Figure 3.

The Engi Slates are well exposed. Outcrops exist around the entrances to the Landesplattenberg, around the Schwarzkopf mines, along the road to Chreuelalp, and in the numerous gullies cutting through the study area. Despite the steep mountainside and dense vegetation, all the outcrops indicated on the map are accessible and were visited. The Eocene marls on top of the Engi Slates are poorly exposed. Outcrops exist only at the head of the main gullies and in some isolated areas.

\section{a) Lithology}

The Engi Slates consist of an alternation of mm- to cm-thick silt and clay layers. In the lower part, several turbiditic sandstone layers of 10-50 cm thickness are intercalated with the silt and clay layers. These sandstone layers are graded and show load marks at their lower boundary, providing a good top-bottom criterium. The silt layers often show straight upper and undulated lower boundaries, providing a good top-bottom criterium as well. Bedding is the dominant structural feature in the Engi Slates and can be observed in almost every outcrop.

Microscopically, the sandstones consist of quartz grains and rock fragments (limestones, dolomites). The silt layers consist of quartz ( $0.1 \mathrm{~mm}$ grain size $)$, calcite, white mica and clay minerals. The clay layers consist of clay minerals, calcite, quartz

312 D. Gasser \& B. den Brok 
(a)

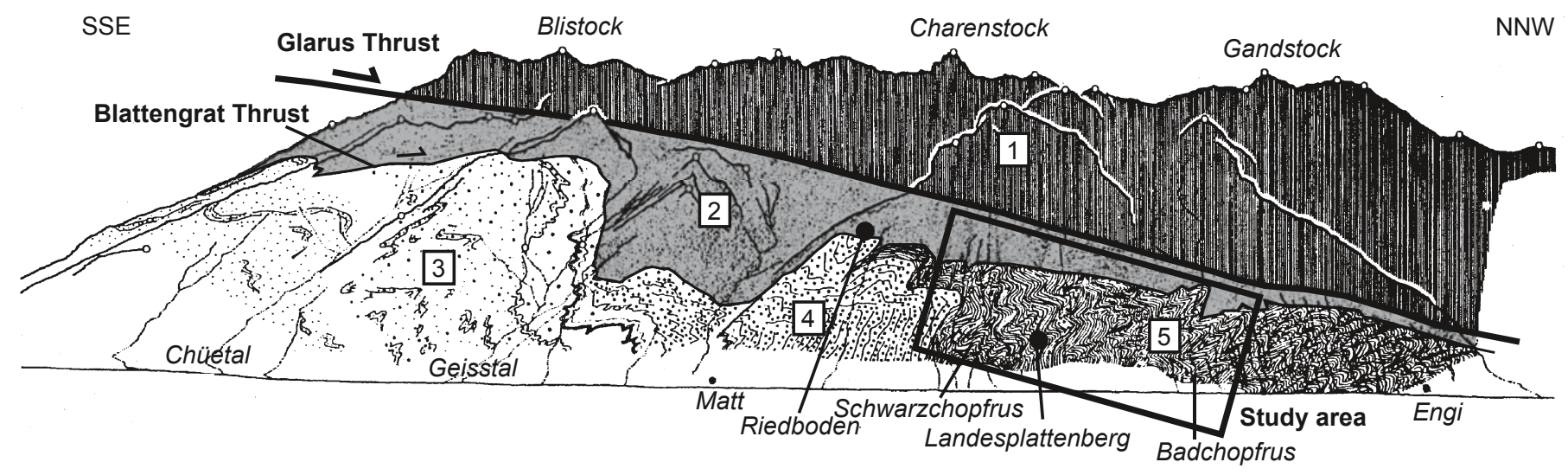

(b)

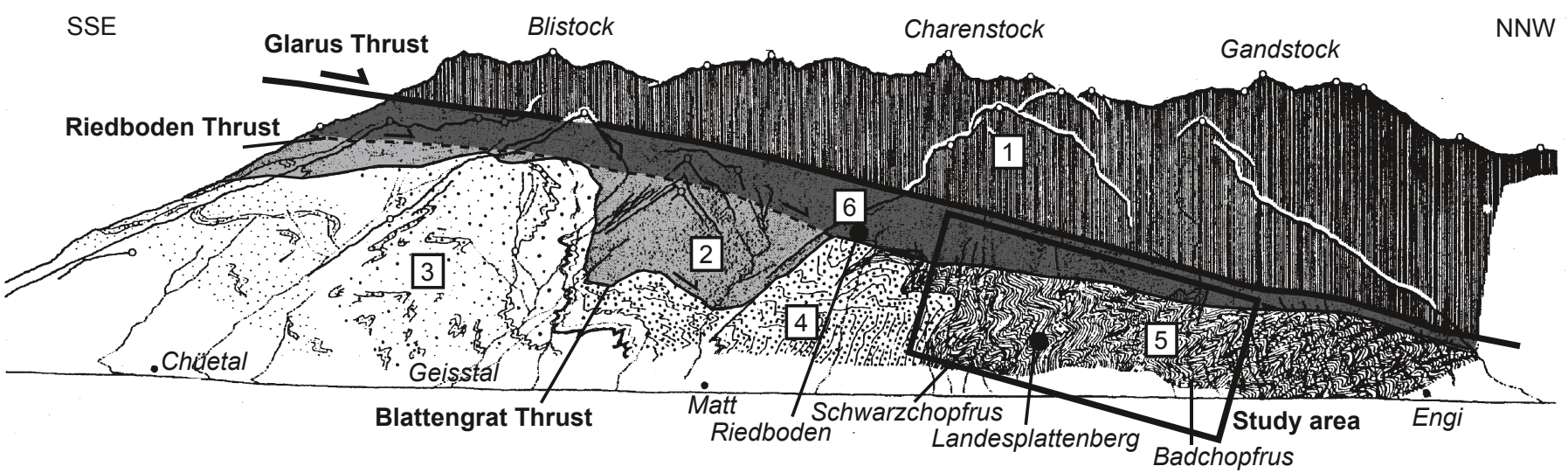

\begin{tabular}{|l|lll}
\hline 1 & Verrucano of Helvetic Nappes & 4 & Matt Sandstones (Matt Formation of NHF) \\
\hline 2 & Blattengrat Nappe & 5 & Engi Slates (Matt Formation of NHF) \\
\hline 3 & Elm Formation of NHF & 6 & Wildflysch Nappe sensu Oberholzer (1942)
\end{tabular}

Fig. 2 (a) Siegenthaler's (1974) geological profile along the eastern side of the Sernft Valley. For location of the profile see Figure 1. Note the presence of the Blattengrat Nappe above the Engi Slates in our study area. (b) Re-interpretation in line with Oberholzer $(1933,1942)$ and our results.

( $<0.05 \mathrm{~mm}$ grain size), white mica and organic material. The silt layers differ from the clay layers both in the larger grain size of quartz and in the higher calcite content.

\section{b) Foliations}

Two foliations were recognized: (i) a bedding-parallel slaty cleavage, and (ii) a tectonic, disjunctive, pressure solution cleavage, further referred to as Plattenberg foliation. The bedding-parallel slaty cleavage is defined by the alignment of de- tritic white mica in the clay layers parallel to the bedding. It is always oriented parallel to the bedding; no folds or other tectonic features related to this foliation have been found. The tectonic Plattenberg foliation is a disjunctive cleavage (Passchier \& Trouw 2005) defined by dark seams of clay minerals and is particularly well developed in the clay layers. In the field it can only be observed with ease where it makes an angle with the bedding. It has a uniform orientation in the study area, dipping $15-40^{\circ}$ towards SE (Fig. 4a). It is the only tectonic foliation in the study area. The bedding-parallel slaty cleavage is 


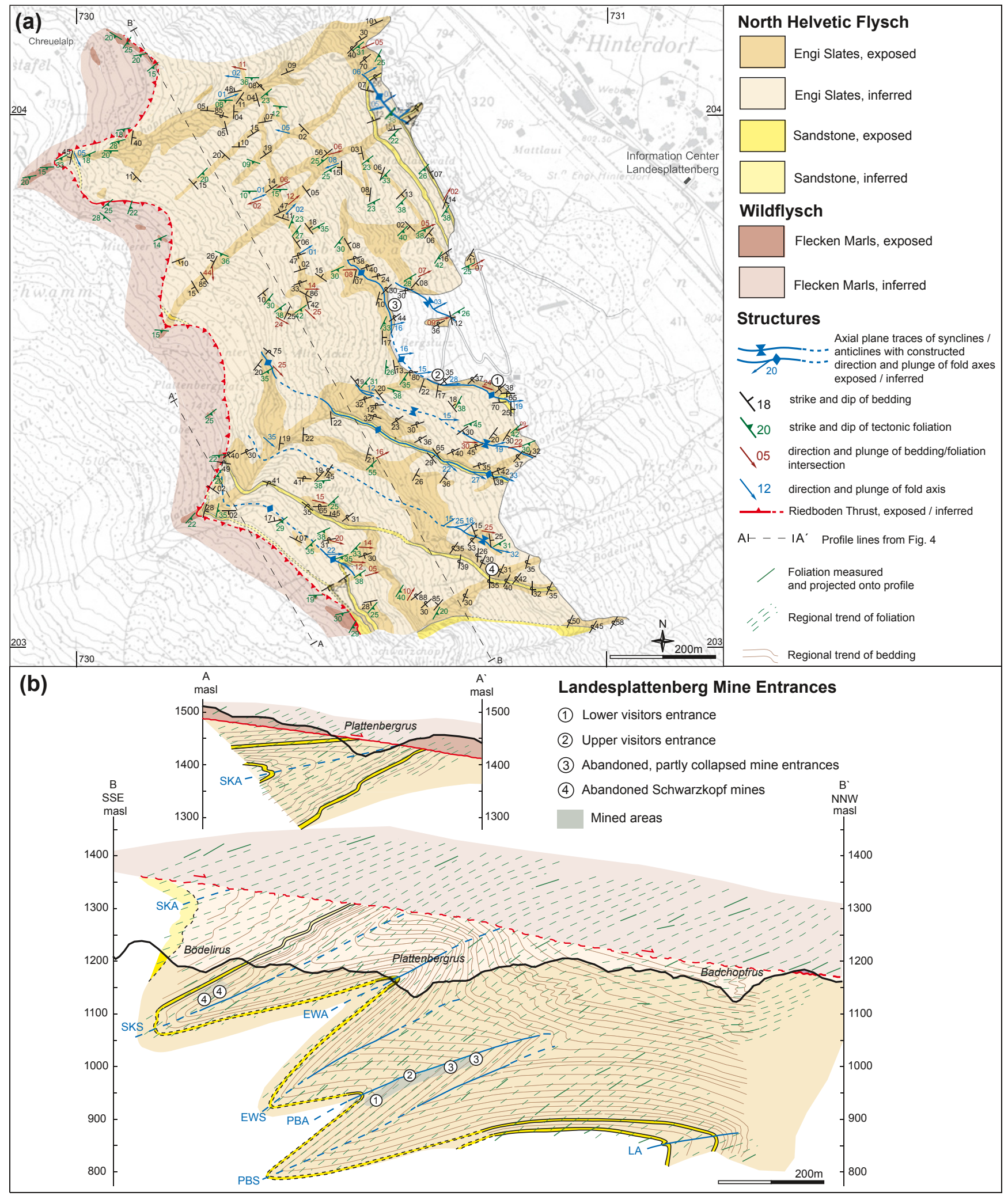

Fig. 3. (a) Geological map of the study area. The upper and lower visitors entrances of Landesplattenberg that are often visited on geological excursions are marked 1 and 2, respectively. Coordinates in Swiss National Grid. Map base: „Katasterplan der Gemeinde Engi“, scale 1:10,000. (b) Tectonic profiles through the study area. Profile lines are indicated on Figure 3a. SKA: Schwarzkopf Anticline; SKS: Schwarzkopf Syncline; EWA: Erlenwald Anticline; EWS: Erlenwald Syncline; PBA: Plattenberg Anticline; PBS: Plattenberg Syncline; LA: Lochrus Anticline. 
responsible for good fissility of the Engi Slates. Where both foliations are parallel, the quality of the Slates is good enough for mining.

\section{c) Folds}

Despite the uniform lithology of the Engi Slates we could determine the large-scale structure of the area with the help of the turbiditic sandstone layers. The Engi Slates appear to be tightly folded at deca- to hectometer scale into NW-vergent folds with straight limbs and sharp hinges. Four large-scale anticlines and three large-scale synclines could be mapped (Fig. 3b). We refer to these folds as Plattenberg $\mathrm{F}_{1}$ folds. They are close to tight symmetrical folds, most of them of type $1 \mathrm{C}$, i.e. the limbs are thinner than the hinges (classification of Ramsay 1967). The normal and inverted limbs are equally thick. An example of such a type $1 \mathrm{C}$ fold is exposed just right of the upper visitors entrance of Landesplattenberg mine (Fig. 5a). Other examples can be found along the partly collapsed mine entrances above the upper visitors entrance (Fig. 5b) and in the Badchopfrus gully (Fig. 5c).

The fold axes of the $F_{1}$ folds were constructed by plotting bedding in a stereonet, whereas the fold axes of smaller $F_{1}$ folds could be measured directly in the field. The fold axes appeared to vary significantly in orientation, but they all plot on one single great circle that corresponds to the axial plane of the folds (135/20, Azimuth/Dip; Fig. 4b). The fact that the fold axes scatter on a great circle, but that the orientation of the axial planes is constant, was also observed by Siegenthaler (1974) and Schmid (1975) further south in the Sernft Valley. It suggests that the Engi Slates were already folded when the large-scale $F_{1}$ folds developed (e.g. Speksnijder 1987). We refer to these hypothetical older folds as pre- $\mathrm{F}_{1}$ folds.

The Plattenberg foliation is oriented sub-parallel to the overturned limbs of the $\mathrm{F}_{1}$ folds (at all scales) and cuts through their axial planes. There is always a significant angle between the axial plane (i.e. the plane connecting the hinge lines of the folds) and the foliation (Fig. 5a-d). Hence, the Plattenberg foliation is not the axial plane foliation to the $\mathrm{F}_{1}$ folds. In the case of the $F_{1}$ Schwarzkopf Syncline (Fig. 3, 5d), it even appeared to cut through the overturned limb in the wrong way, i.e. the foliation is steeper than the bedding, whereas it should have been the other way round if it would have been an axial plane foliation. These observations indicate that the $F_{1}$ folds are older than the Plattenberg foliation.

Intersection lineations between bedding and Plattenberg foliation were also determined. They spread along the same great circle as the $\mathrm{F}_{1}$ fold axes (Fig. $4 \mathrm{~b}$ ). This is not a surprise, because the Plattenberg foliation is parallel to the overturned limbs of the $F_{1}$ folds.

Locally, open folds with the Plattenberg foliation as an axial plane foliation were observed. These folds most likely developed simultaneously with the Plattenberg foliation. They will therefore be referred to as Plattenberg $\mathrm{F}_{2}$ folds. A good example of an $F_{2}$ fold is exposed just above the lower visitors entry of Landesplattenberg mine (Fig. 5e). (a)

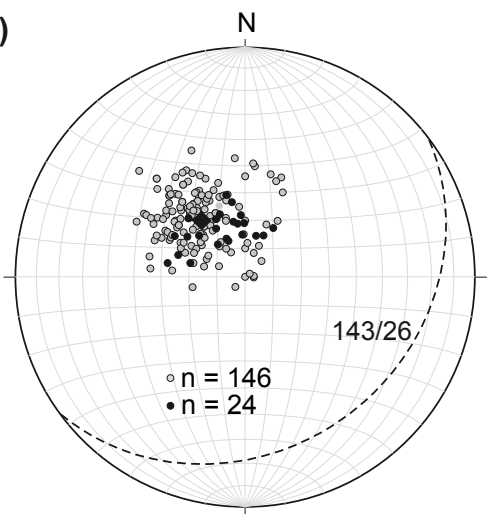

- Poles to Plattenberg foliation in Engi Slates

- Poles to Plattenberg foliation in Flecken Marls

constructed mean value of Plattenberg foliation

(pole)

- constructed mean value of Plattenberg foliation

(great circle) (b)

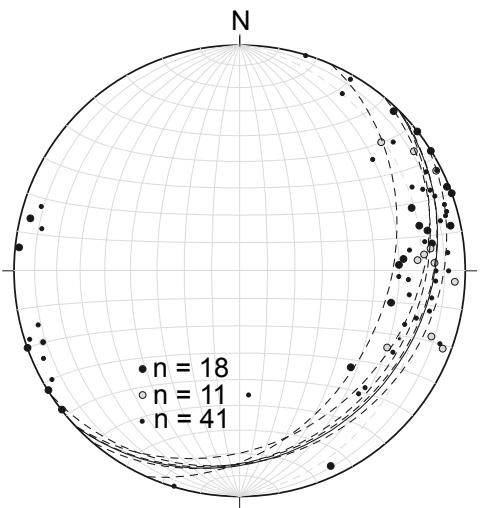

- measured fold axes

constructed fold axes

- measured bedding/foliation intersection

'- constructed axial planes of major folds

best-fit great circle for fold axis and bedding/foliation intersection scattering 135/20 (c)

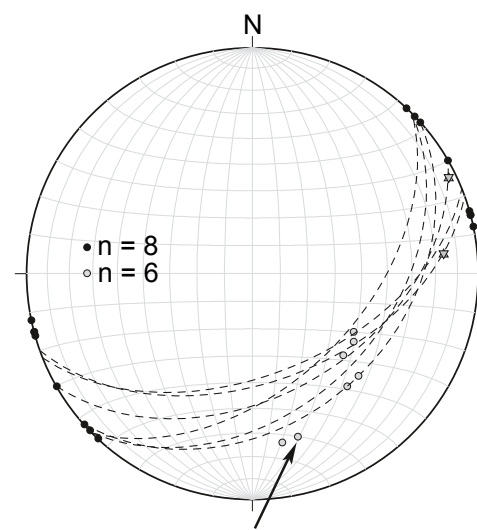

stretching lineation outside Plattenberg mine

$$
\begin{aligned}
& \text { Stretching lineation inside } \\
& \text { Plattenberg mine } \\
& \text { Strike of Boudin axis } \\
& \text { s. Fold axes of Plattenberg } \\
& \text { anticline and syncline } \\
& \text { - orientation of bedding planes } \\
& \text { in the Plattenberg mine }
\end{aligned}
$$

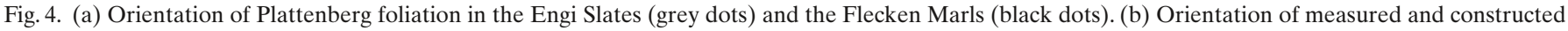

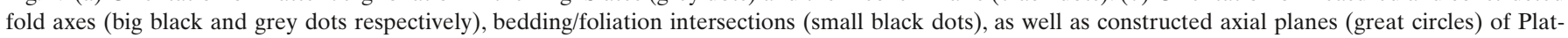

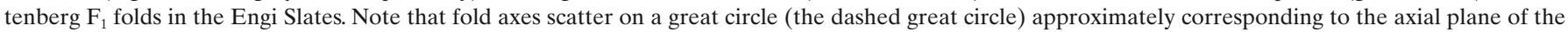

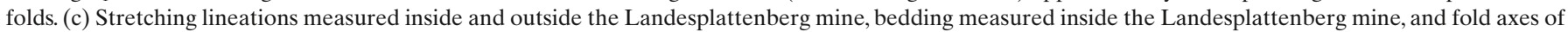
Plattenberg Anticline and Syncline. Lower hemisphere equal area projections. 

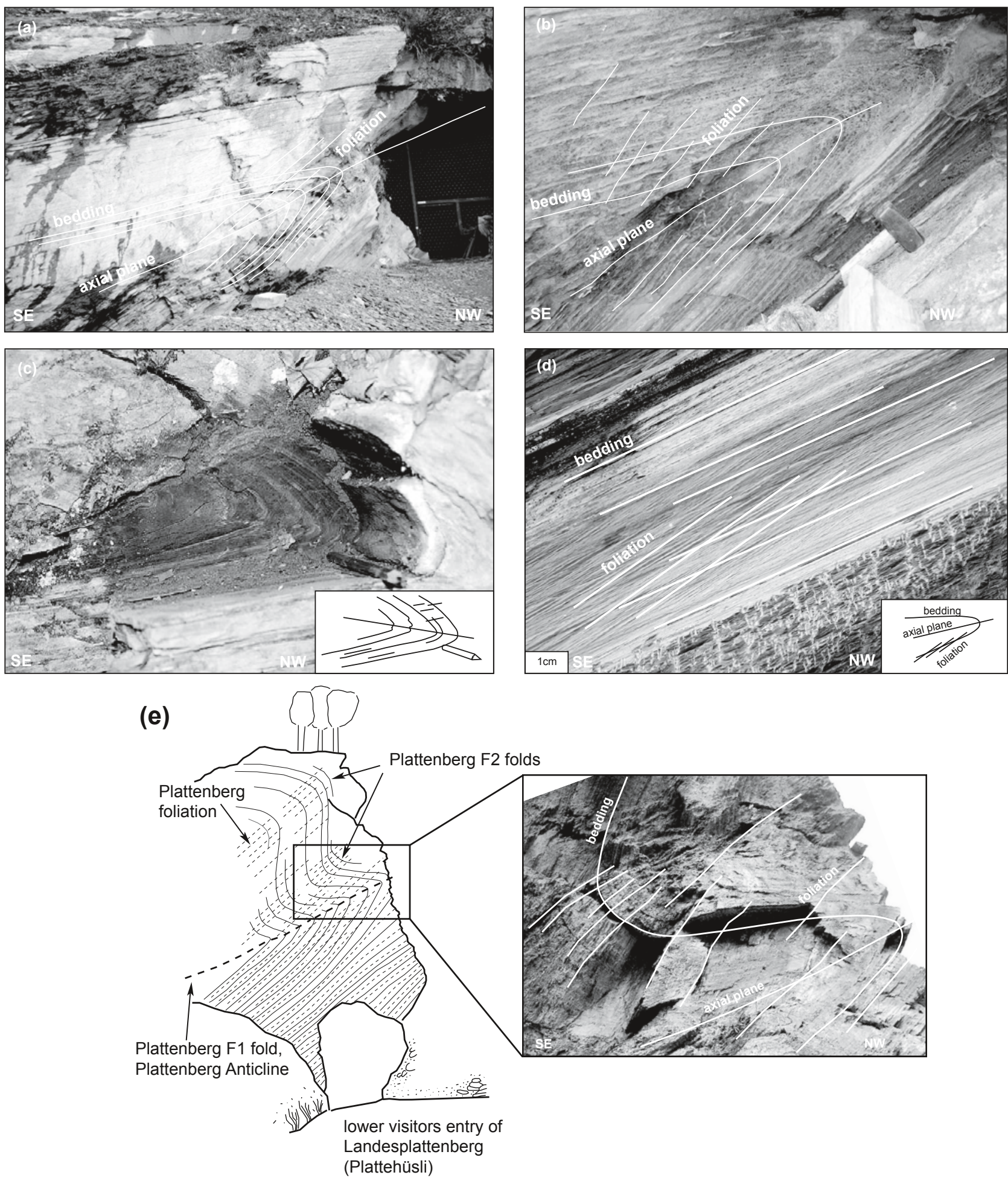

Fig. 5. (a) Photograph of upper visitors entry of the Landesplattenberg mine showing an example of a Plattenberg $F_{1}$ fold (the hinge of the Plattenberg Anticline). The Plattenberg foliation is oriented parallel to the overturned limb and cuts through the axial plane of the fold. The entrance to the mine is $\sim 5 \mathrm{~m}$ high. (b) Photograph of an example of a Plattenberg $\mathrm{F}_{1}$ fold between the upper visitors entrance of Landesplattenberg and the abandoned mine entrances (Fig. 3). Normal and inverted limb are almost equally thick; the foliation is parallel to the overturned limb and cuts through the axial plane of the fold. (c) Photograph of a Plattenberg $\mathrm{F}_{1}$ fold in the Badchopfrus (Fig. 3). Normal and inverted limb are almost equally thick. (d) Photograph illustrating relationship between sedimentary bedding and Plattenberg foliation near the Schwarzkopf mines. The bedding is overturned, the foliation cuts through the bedding with the wrong orientation for an axial plane foliation. (e) Sketch and photograph of the lower visitors entrance of Landesplattenberg mine. Just above the entrance, the hinge of the $F_{1}$ Plattenberg Anticline is exposed. The inverted limb is oriented parallel to the Plattenberg foliation. Above this anticline, open Plattenberg $\mathrm{F}_{2}$ folds with the foliation as axial plane foliation are exposed. 


\section{d) Stretching lineation and boudinage}

According to Wettstein (1886) the slates from the Landesplattenberg mine show a pronounced stretching lineation. The fish fossils found in these slates are stretched by amounts of up to 2.4 parallel to this lineation. Unfortunately the lineation is extremely difficult to recognize in the field. We were able to determine its orientation at very few localities only, notably inside the Landesplattenberg mine and at one locality outside the mine (Fig. 4c). More commonly we observed boudinaged silt layers, both in the normal as well as in the inverted limbs of the Plattenberg $F_{1}$ folds. The boudin axes are oriented parallel to the fold axes of the $F_{1}$ folds. The stretching lineations that we were able to measure made an angle of about $70^{\circ}$ with the boudin axes and the $\mathrm{F}_{1}$ fold axes (Fig. 4c). The data are too sparse to judge whether boudinage and stretching took place before, or after the development of the $\mathrm{F}_{1}$ folds.

\section{e) Upper tectonic boundary of the Engi Slates}

The Engi Slates are bounded upwards by a thrust, which we refer to as Riedboden Thrust (not to be confused with the Glarus Thrust). This thrust corresponds to a major change in local geomorphology. The steep and rugged slope below the thrust, with many outcrops of Engi Slates, gives way to a much flatter and smoother slope above the thrust, where light-grey marls are exposed in the main gullies and along the path to Chreuelalp. These marls show characteristic dark stains (believed to be due to bioturbation) and belong to the Eocene Flecken Marl Formation (Siegenthaler 1974, Lihou 1995).

The relationship between the Riedboden Thrust and the structures in the Engi Slates is well exposed near the upper part of the Plattenbergrus gully (Fig. 3). The overturned sandstone beds, which run from the Schwarzkopf mines in the south-east to the Plattenbergrus gully in the north-west, are unconformably overlain by the Flecken Marl Formation just below Oberer Plattenbergplatz. The thrust contact itself is not exposed. The same sandstones reappear higher up in the Plattenbergrus gully in normal position, representing the normal limb of the Schwarzkopf Anticline. They are also unconformably overlain by the Flecken Marl Formation. So it appears that the hinge of the Schwarzkopf Anticline, which is exposed north of Schwarzchöpf, is unconformably cut-off by the Riedboden Thrust just north of the Plattenbergrus gully.

The thrust zone is well exposed in the upper Plattenbergrus gully, but the thrust contact itself could not be identified. Between the uppermost clearly identifiable Engi Slates (characteristic alternation of silt-and clay layers) and the lowermost clearly identifiable Flecken Marls (characteristic dark stains, i.e. bioturbation) there is a 4 to $5 \mathrm{~m}$ wide zone of marls that we were unable to attribute to either Engi Slates or Flecken Marls. A thrust as tectonic feature (e.g. shear zone) was not observed. The only structural feature recognized was the southeast dipping Plattenberg foliation cutting through the contact zone. No other (older or younger) foliations were observed.
The Riedboden Thrust may be folded at meter-scale by open Plattenberg $F_{2}$ folds, but we were unable to verify this, since the outcrop is only a few meters wide. At large scale the thrust is a straight surface, dipping $16-25^{\circ}$ towards NE, at least in the area we mapped (Fig. 6).

The fact that the Plattenberg $F_{1}$ folds are unconformably cut-off by the Riedboden Thrust, whereas the Plattenberg foliation cuts through the Rietboden Thrust, corroborates our earlier mentioned argument that the Plattenberg $F_{1}$ folds must be older than the Plattenberg foliation.

\section{Model for the tectonic evolution of the Engi Slates}

Our model for the tectonic evolution of the Engi Slates is illustrated in Figure 7. After deposition and compaction of the

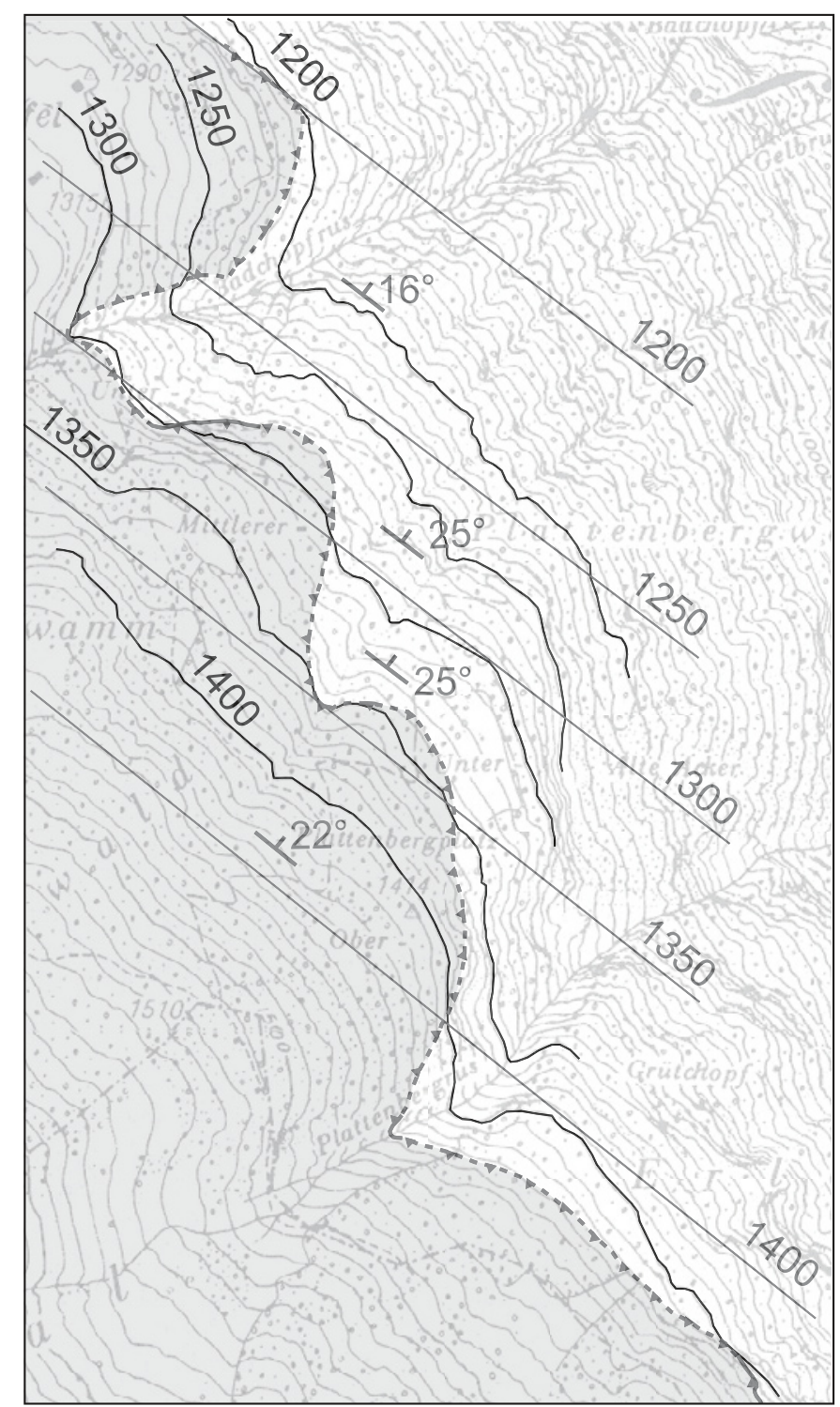

Fig. 6. Detail of geological map with contour lines of the Riedboden Thrust suggesting that the thrust corresponds to a straight, $16-25^{\circ} \mathrm{NE}$-dipping plane. 
Engi Slates (Figs. 7a-b), an early, pre-Plattenberg $\mathrm{F}_{1}$ folding phase must have taken place, as was inferred from the scatter of Plattenberg $F_{1}$ fold axes along the $F_{1}$ axial planes (Fig. $7 \mathrm{c}$ ). Then the Engi Slates were folded on a regional scale during the Plattenberg $\mathrm{F}_{1}$ phase, but no axial plane cleavage developed (Fig. 7d). The $F_{1}$ folds were subsequently unconformably cut-off by the Riedboden Thrust, along which Eocene Flecken Marls were placed on top of the lower Oligocene Engi Slates (Fig. 7e). Thereafter, the Plattenberg foliation developed, both in the Engi Slates and the Flecken Marls as an axial plane foliation to open Plattenberg $\mathrm{F}_{2}$ folds (Fig. 7f).

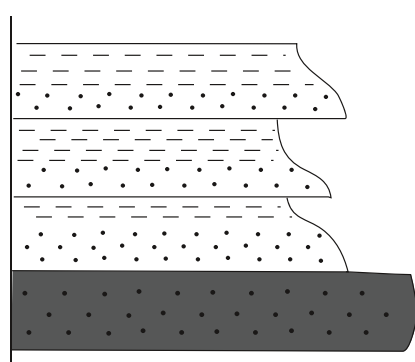

slates

sst

a) Deposition

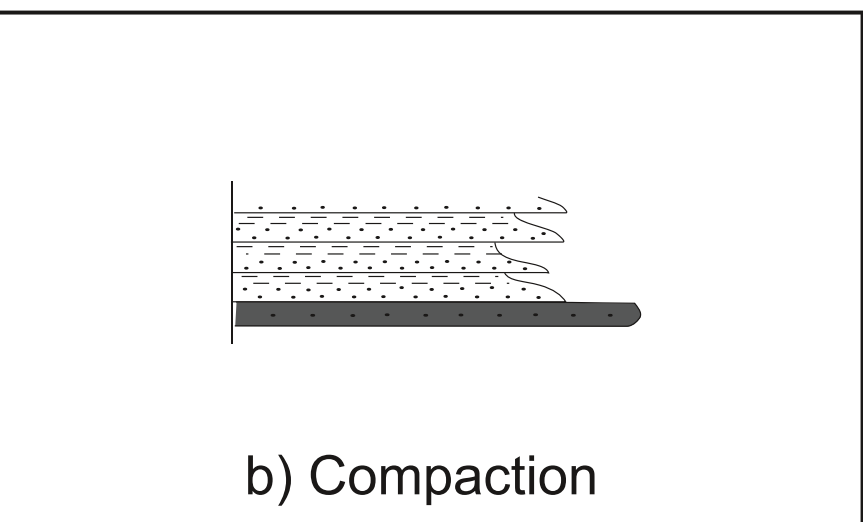

SSE

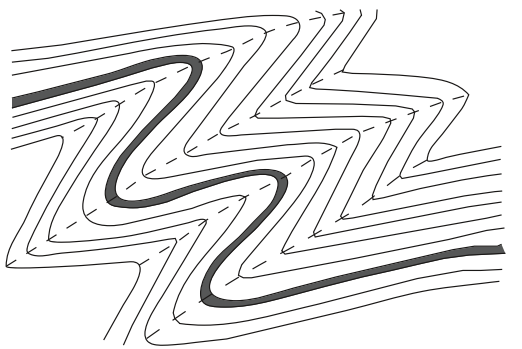

NNW $\sim \mathrm{W}$

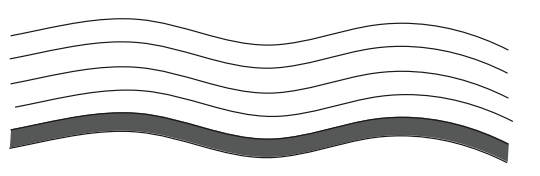

c) Pre- $F_{1}$ folding

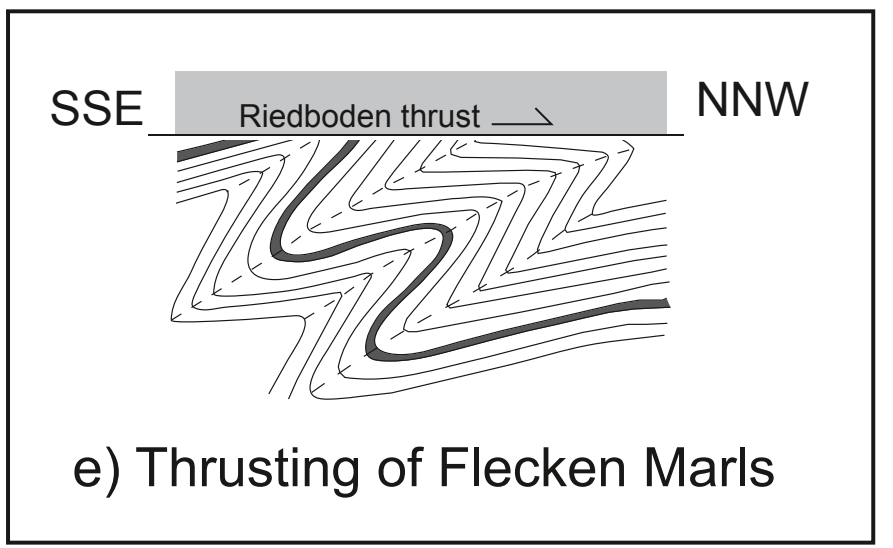

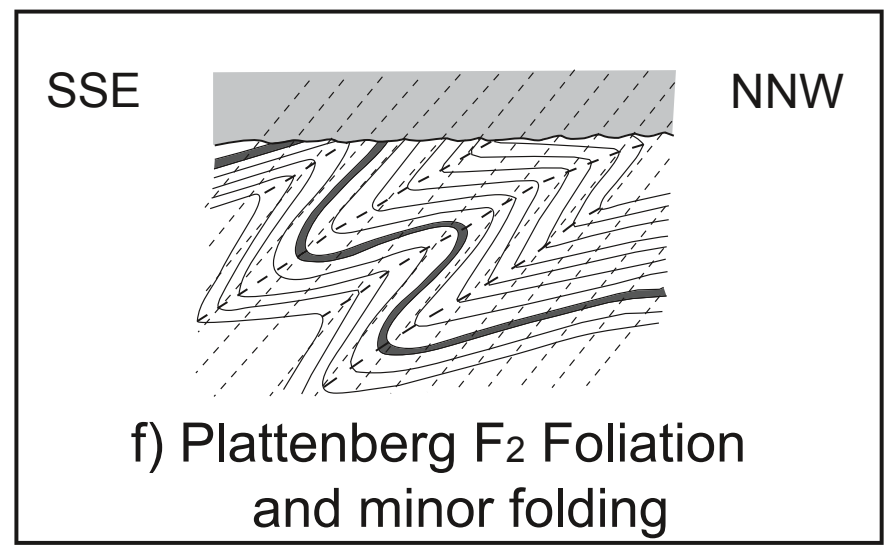

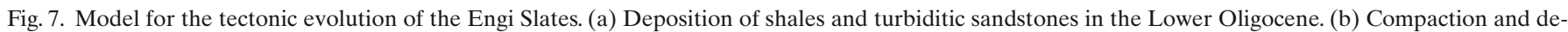

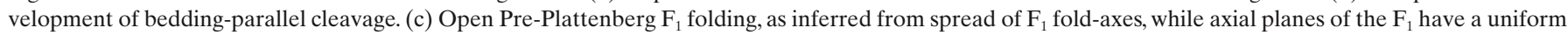

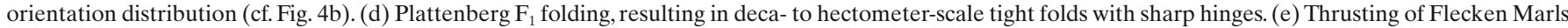

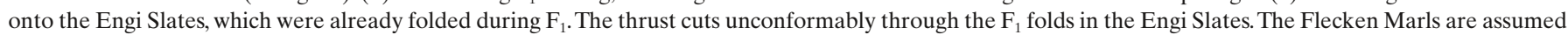
to belong to the Wildflysch Nappe, such as on Oberholzer's (1942) geological map. (f) Development of SE-dipping Plattenberg foliation plus open $F_{2}$ folding.

318 D. Gasser \& B. den Brok 


\section{Comparison with previous work}

\section{a) Phase correlations}

Our Plattenberg $\mathrm{F}_{1}$ folds correspond to phase 2 folds of Schmid (1975) and to Calanda phase folds of Milnes \& Pfiffner (1977). Our Plattenberg foliation corresponds to phase 2 foliation of Schmid (1975) and to Calanda phase foliation of Milnes \& Pfiffner (1977). The relationships are depicted in Figure 8. In the following, we will refer to Schmid's (1975) phase 2 as Calanda phase as well. According to Schmid (1975) and Milnes \& Pfiffner (1977) the Calanda phase foliation is the axial plane foliation to the Calanda phase folds and developed simultaneously with the folds. According to us these folds and foliation developed during two separate phases: the foliation cuts through the axial plane of the folds and therefore developed after the folding. Moreover, the folds are cut-off by the Riedboden Thrust, whereas the foliation cuts through the Riedboden Trust.

\section{b) Fold geometries and their relationship to the foliation}

Schmid (1975) and Pfiffner (1977, 1978, 1980) report geometries from folds they observed in the Infrahelvetic Complex.
Schmid (1975) describes Calanda phase folds that developed in the NHF Unit in the Sernft Valley, including examples from the Engi Slates near the Landesplattenberg. He describes them as tight folds with the Calanda phase foliation oriented sub-parallel to the inverted limbs. Similarly, Pfiffner $(1977,1978,1980)$, who studied the fold geometry of Calanda phase folds in the Infrahelvetic Complex in the area around Kistenpass $(\sim 15 \mathrm{~km}$ SW of our study area) and Kunkelspass (NW of Chur), likewise describes tight folds with Calanda phase foliation oriented parallel to the overturned limb. Both authors report that the foliation is not only sub-parallel to the inverted limb, but also parallel to the fold axial plane. This requires extreme thinning of the inverted limb compared to the normal limb, such as schematically depicted by Milnes (1981, in Furrer \& Leu 1998; Fig. 9a) as a representative example of such folds in the Engi Slates at the Landesplattenberg.

Our observations are different. First, we observed that the Plattenberg foliation is indeed oriented parallel to the overturned limbs, but not parallel to the axial planes of the $F_{1}$ folds. It cuts through them with a significant angle. Second, we observed that the inverted limbs are generally not much thinner than the normal limbs (Fig. 5). The fold geometry such

\begin{tabular}{|c|c|c|c|}
\hline Authors & Schmid (1975) & Milnes \& Pfiffner (1977) & this study \\
\hline $\begin{array}{l}\text { Study } \\
\text { area }\end{array}$ & $\begin{array}{l}\text { Infrahelvetic Complex } \\
\text { Sernft Valley }\end{array}$ & $\begin{array}{l}\text { Infrahelvetic Complex } \\
\text { Kunkels- and Kistenpass }\end{array}$ & $\begin{array}{l}\text { Infrahelvetic Complex } \\
\text { Landesplattenberg }\end{array}$ \\
\hline \multirow{6}{*}{ 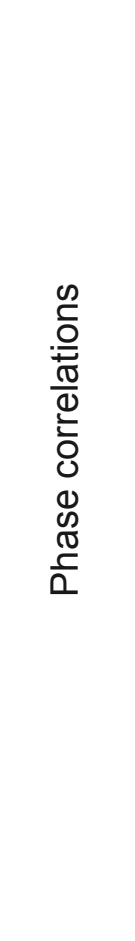 } & $\begin{array}{l}\text { Phase } 3 \\
\text { Development of Glarus } \\
\text { Thrust and crenulation } \\
\text { cleavage below Glarus Thrust }\end{array}$ & \begin{tabular}{l}
\multicolumn{1}{c|}{ Ruchi phase } \\
Development of crenulation cleavage \\
below Glarus Thrust and further \\
movement along Glarus Thrust
\end{tabular} & $\begin{array}{l}\text { Thrusting along Glarus Thrust } \\
\text { Ruchi phase } \\
\text { foliation and folding }\end{array}$ \\
\hline & Thrusting of Subhelvetic Units & & Thrusting of Subhelvetic Units \\
\hline & \multirow[t]{2}{*}{$\begin{array}{l}\text { Phase } 2 \\
\text { Ductile penetrative } \\
\text { phase of folding with } \\
\text { axial plane foliation }\end{array}$} & \multirow[t]{2}{*}{$\begin{array}{l}\text { Calanda phase } \\
\text { Ductile penetrative deformation } \\
\text { (folding and foliation development) } \\
\text { movement along Glarus Thrust }\end{array}$} & $\begin{array}{l}\text { Plattenberg F2 phase } \\
\text { Penetrative tectonic foliation and } \\
\text { meter- to decameter scale folding } \\
\text { Thrusting of } \\
\text { Wildflysch Nappe }\end{array}$ \\
\hline & & & $\begin{array}{l}\text { Plattenberg F1 phase } \\
\text { Folding up to hectometer-scale }\end{array}$ \\
\hline & & $\begin{array}{l}\text { Cavestrau phase } \\
\text { Thrusting of Subhelvetic Units }\end{array}$ & \\
\hline & $\begin{array}{c}\text { Phase } 1 \\
\text { Diverticulation, } \\
\text { gravity sliding? } \\
\text { of Blattengrat and } \\
\text { Sardona Nappes }\end{array}$ & $\begin{array}{l}\text { Pizol phase } \\
\text { Emplacement of } \\
\text { Blattengrat and } \\
\text { Sardona Nappes }\end{array}$ & $\begin{array}{c:c}\text { Emplacement of } & \text { Pre F1 folding } \\
\text { Blattengrat and } & \text { Pardona Nappes }\end{array}$ \\
\hline
\end{tabular}

Fig. 8. Table showing the relationships between the deformational phases defined in the Infrahelvetic Complex by Schmid (1975), Milnes \& Pfiffner (1977) and the present study. 
(a)

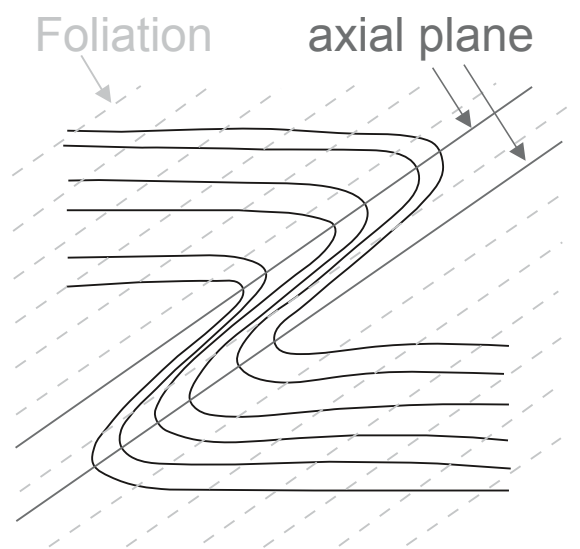

(b)

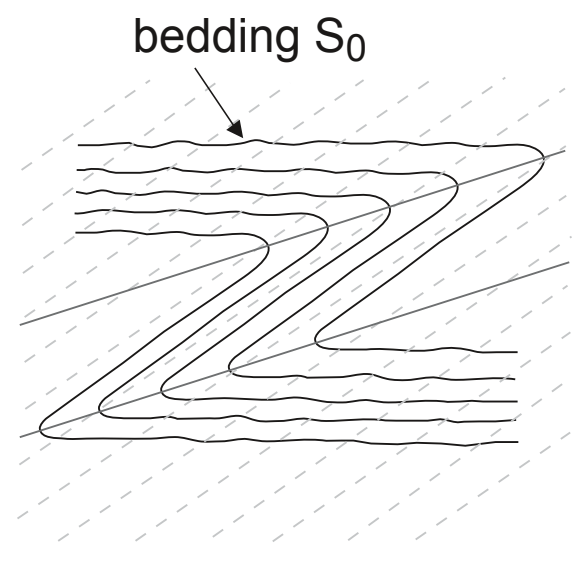

Fig. 9. (a) Fold geometry such as observed by Schmid (1975) and Pfiffner $(1977,1978)$. The foliation is oriented parallel to the axial plane and to the inverted limbs of the folds. The folds and foliation is assumed to have developed simultaneously. (b) Geometry of folds and foliation such as observed in the present study (cf. Fig. 5). The foliation is oriented parallel to the inverted limb, but cuts through the axial plane of the folds. It developed after the folding. as we observed in the Engi Slates of the Landesplattenberg area is schematically depicted in Figure 9b. In fact, the Calanda phase fold and foliation drawn by Pfiffner (1978, fig. 2b) is almost identical to the folds observed by us, also showing foliation oriented parallel to the inverted limb, with both the inverted and the normal limb being almost equally thick. We cannot imagine how this geometry can be interpreted else than by a first phase of folding $\left(F_{1}\right)$ without development of an axial plane foliation, followed by a second phase of further coaxial folding $\left(\mathrm{F}_{2}\right)$ with foliation development parallel to the overturned limb of the $F_{1}$ folds. The $Y$-axis of incremental strain during $\mathrm{F}_{2}$ must have been approximately parallel to the $\mathrm{Y}$-axis of finite strain of the $\mathrm{F}_{1}$ folds, whereas the $\mathrm{XY}$-plane of incremental strain during $\mathrm{F}_{2}$ must have been $\sim 20^{\circ}$ steeper than the XY-plane of finite strain of the $F_{1}$ folds and approximately parallel to the overturned limbs of the $F_{1}$ folds. The limbs may have rotated further towards parallelism with the foliation during $\mathrm{F}_{2}$.

Note that Schmid's (1975) phase 3 folds and crenulation foliation, corresponding to Milnes \& Pfiffner's (1977) Ruchi phase folds and crenulation foliation, did not develop in our study area. As mentioned by these authors, Ruchi phase structures exclusively developed in a zone just below the Glarus Thrust. Ruchi phase crenulation foliation is well exposed in the upper Chüetal, directly south of our study area, where it crenulates the Calanda phase foliation (Plattenberg foliation in our terminology).

\section{c) Truncated folds and the Riedboden Thrust}

The Flecken Marls above the Engi Slates are commonly attributed to the Blattengrat Nappe. The Riedboden Thrust is consequently assumed to correspond to the thrust at the base of the Blattengrat Nappe, further referred to as Blattengrat Thrust (Bisig 1957, Siegenthaler 1974, Schmid 1975, Lihou 1995; Fig. 2a). We prefer another interpretation.
Thrusting of the Blattengrat Nappe onto the NHF Unit took place during phase 1 of Schmid (1975), corresponding to the Pizol phase of Milnes \& Pfiffner (1977). The Blattengrat Nappe was subsequently folded together with the underlying NHF Unit (including the Engi Slates) during the Calanda phase (Schmid 1975, Milnes \& Pfiffner 1977). A good example of a large-scale Calanda phase fold folding the Blattengrat Thrust is exposed near the village of Matt, a few kilometers south of our study area (Fig. 2a). The Calanda phase foliation cuts through the folded Blattengrat Thrust (see e.g. Schmid 1975, fig. 2).

The Riedboden Thrust, however, is not folded by the Calanda phase folds (Plattenberg $\mathrm{F}_{1}$ folds in our terminology). The thrust cuts straightly through the Calanda folds. In Siegenthaler's (1974) profile through our study area (Fig. 2a) the Blattengrat Thrust, corresponding to our Riedboden Thrust, is also drawn straight. It only shows one single remarkable tight fold just north of Badchopfrus. This outcrop pattern at Badchopfrus may indeed suggest the existence of this fold, but we could not discover a corresponding fold in the underlying Engi Slates. According to us, the outcrop pattern is better explained by intersection between the rugged topography and a straight, 16-25 NE-dipping thrust plane (see Fig. 6).

So it appears that the Blattengrat Trust is folded by Calanda phase folds, whereas the Riedboden Thrust cuts through these folds. These cannot be the same thrusts. We therefore correlate the Riedboden Thrust with another thrust. On the geological map of the Glarus Alps drawn by Oberholzer (1942) the Flecken Marls above the Engi Slates are not attributed to the Blattengrat Nappe, but to the so-called "Wildflysch" ( $w_{f}$ on his map; Wildflysch Nappe in Oberholzer 1933; Fig. 2b). The Riedboden Thrust would in this case correspond to the base of the Wildflysch Nappe, which cuts unconformably through Calanda phase folds (Plattenberg $\mathrm{F}_{1}$ folds in our terminology) just south of our study area. For example, on Oberholzer's (1942) map, the base of the Wildflysch Nappe unconformably cuts through

320 D. Gasser \& B. den Brok 


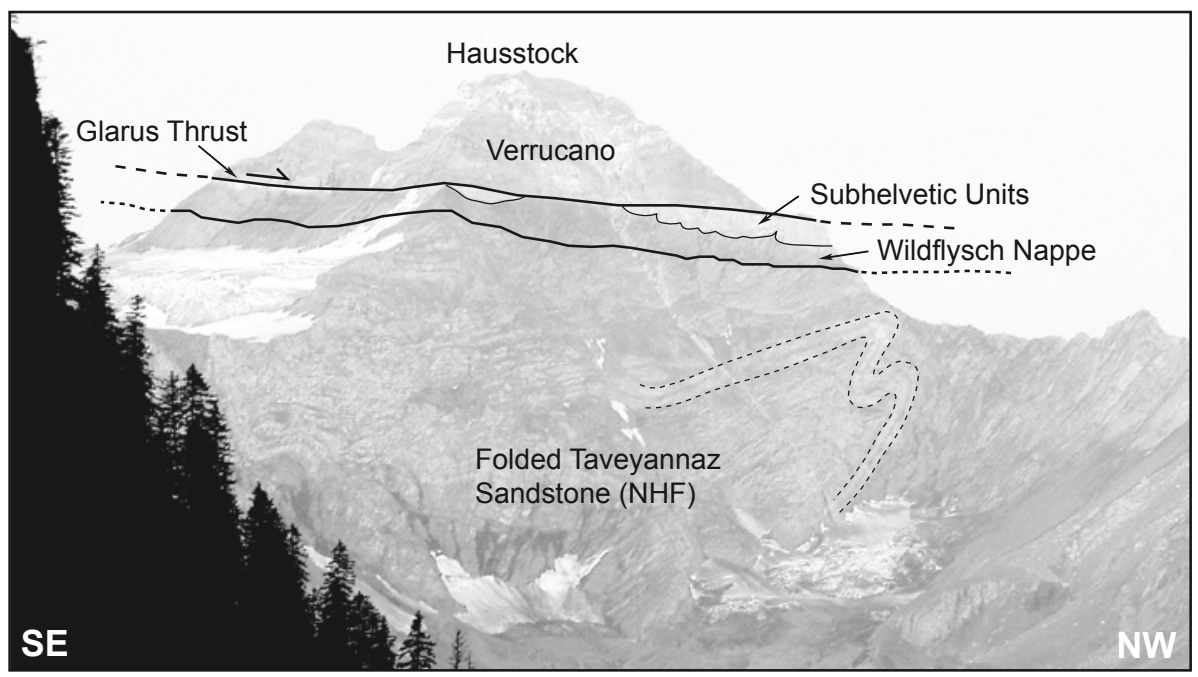

Fig. 10. Photograph of north-east face of Hausstock in the southern Sernft Valley. The dark slates below the Glarus thrust belong to Oberholzer's $(1933,1942)$ Wildflysch nappe, the base of which unconformably cuts through Calanda phase folds in the underlying Taveyannaz Sandstone Formation of the NHF. the aforementioned Calanda phase syncline in the Blattengrat Nappe near the village of Matt (Fig. 2b). The folded Blattengrat Thrust is cut-off by the base of the Wildflysch Nappe just east of Riedboden Alp. Other synclines in the Blattengrat Nappe west of Elm, notably at Empächli Alp and Bischof Alp seem to be cut-off by the base of the Wildflysch Nappe on Oberholzer's (1942) map as well. In the north-east face of Hausstock, another large-scale Calanda phase fold in the Taveyannaz Sandstone Formation of the NHF Unit seems to be unconformably cut-off by the base of the Wildflysch Nappe (Fig. 10).

Oberholzer (1942) drew Wildflysch $\left(w_{f}\right)$ almost everywhere below the Glarus Thrust in the Sernft Valley. Geological mapping carried out in the whole Sernft Valley by one of the authors (BdB, geological mapping of map sheet Elm 1:25,000 for the Swiss Geological Survey, work in progress) revealed, that this Wildflysch Nappe consists of (i) a lower part that was renamed Sardona Flysch by Leupold (1942) (later referred to as Sardona Nappe: see e.g. Lihou 1996a, 1996b), and (ii) an upper chaotic part (Schmid 1975), which is a (probably tectonic) mélange of rocks from the Sardona Nappe, Blattengrat Nappe and NHF Unit. In the western Sernft Valley Oberholzer's (1942) Wildflysch $\left(w_{f}\right)$ entirely seems to correspond to this mélange, which lies as a roughly 5 to $100 \mathrm{~m}$ thick, more or less continuous sheet or nappe below the Glarus Thrust. Single components of the mélange may locally be up to several hundreds of meters in size. For example, hectometer-size olistholith-like exotic bodies of Nummulitic limestone from the Blattengrat Nappe occur in this Wildflysch mélange west of Matt and Elm in the upper Geisstal Alp and the upper Chüeboden Alp (Oberholzer 1942).

According to our interpretation, the Flecken Marls on top of the Engi Slates are part of a large olistolith or fragment within the Wildflysch Nappe, much like the Nummulitic limestone fragments in the Wildflysch Nappe in the upper Geisstal Alp and the upper Chüeboden Alp further south. The emplacement of the Wildflysch Nappe should accordingly have taken place after Plattenberg $F_{1}$ folding and before Plattenberg $F_{2}$ folding and foliation development.

On the profiles through the Glarus Alps made by Schmid (1975) and Lihou (1996a) the Calanda phase folds in the Infrahelvetic Complex are also clearly cut-off unconformably, but by the Glarus Thrust itself. Our observations suggest that this unconformity should not be located at the Glarus Thrust itself, but at the base of the underlying mélange of the Wildflysch Nappe.

\section{d) Relationship between our observations and the Glarus Thrust}

The Plattenberg foliation cuts through the Riedboden Thrust, passes upwards through the mélange of the Wildflysch Nappe, and bends northwards into parallelism with the base of the Subhelvetic Units below the Glarus Thrust. These units were therefore emplaced onto the mélange of the Wildflysch Nappe after the development of the Plattenberg foliation, i.e. after our Plattenberg $\mathrm{F}_{2}$ folding phase (Fig. 8). The steeply South-dipping Ruchi phase crenulation foliation, which crenulates the Plattenberg foliation, is the axial plane foliation of centimeter- to decameter-scale cuspate-lobate folds in the lower boundary of the Subhelvetic Units. The Ruchi phase therefore must have taken place after the emplacement of the Subhelvetic Units onto the mélange of the Wildflysch Nappe. The Ruchi phase foliation bends northwards into parallelism with the Lochseiten tectonite of the Glarus Thrust, just $\sim 10 \mathrm{~cm}$ below the thrust. The Glarus Thrust consequently developed after the Ruchi phase.

\section{Conclusion}

Our study shows that the Engi Slates were folded on a deca- to hectometer scale during the Plattenberg $\mathrm{F}_{1}$ phase, corresponding to phase 2 folding of Schmid (1975) and to Calanda phase folding of Milnes \& Pfiffner (1977). These folds are unconform- 
ably cut-off by the Riedboden Thrust at the base of a (tectonic?) mélange mapped by Oberholzer (1942) as Wildflysch $\left(w_{f}\right)$. A tectonic foliation subsequently developed during the Plattenberg $\mathrm{F}_{2}$ folding phase. This Plattenberg foliation corresponds to phase 2 foliation of Schmid (1975) and Calanda phase foliation of Milnes \& Pfiffner (1977). It cuts through the Riedboden Thrust and developed both in the Engi Slates and in the overlying Eocene Flecken Marls of the Wildflysch Nappe. Open Plattenberg $\mathrm{F}_{2}$ folds probably folded the Riedboden Thrust on a meter- to decameter scale.

Our results differ from previous studies in the Infrahelvetic Complex in three ways: (i) the main tectonic foliation in the area around the Landesplattenberg (Plattenberg foliation in our terminology) is not the axial plane foliation to the major folds (Plattenberg $\mathrm{F}_{1}$ folds in our terminology). In most cases the Plattenberg foliation is oriented parallel to the overturned limb of the $F_{1}$ folds and cuts through the axial plane of the $F_{1}$ folds. The Plattenberg foliation is therefore younger than the $F_{1}$ folds. It developed during the Plattenberg $F_{2}$ phase. (ii) The overlying Riedboden Thrust was not folded together with the underlying Engi Slates during the Plattenberg $F_{1}$ phase. The $F_{1}$ folds are cut-off unconformably by the Riedboden thrust, but the Plattenberg foliation cuts through the thrust. (ii) The Eocene Flecken Marls above the Engi Slates do not belong to the Blattengrat Nappe, but to the Wildflysch Nappe, such as already proposed by Oberholzer $(1933,1942)$.

\section{Acknowledgements}

This contribution is dedicated to Martin Burkhard, who encouraged the first author to present the results of her diploma thesis to a wider audience. We thank Neil Mancktelow and Heinz Furrer for fruitful discussions and Geoff Milnes and Adrian Pfiffner for critical and very useful reviews.

\section{REFERENCES}

Bisig, W.K. 1957: Blattengratflysch und Sardonaflysch im Sernftal nördlich der Linie Richetlipass - Elm - Ramintal - Grosse Scheibe. PhD Thesis Nr. 2435, ETH Zürich, Switzerland, 239 pp.

Fischer, H. \& Villa, I. 1990: Erste K-Ar- und ${ }^{40} \mathrm{Ar} /{ }^{39} \mathrm{Ar}$-Hornblende-Mineralalter des Taveyannaz-Sandsteins. Schweizerische Mineralogische und Petrographische Mitteilungen 70, 73-75.

Furrer,H. \& Leu, B. 1998: Der Landesplattenberg Engi. Forschungsgeschichte, Fossilien und Geologie. Stiftung Landesplattenberg, Engi, $131 \mathrm{pp}$.

Gasser, D. 2006: Vom Meeresboden auf das Hausdach - tektonische Entwicklung der Engi-Dachschiefer, unpublished Diploma thesis, ETH Zuerich, Switzerland, $125 \mathrm{pp}$.
Leupold, W. 1942: Neue Beobachtungen zur Gliederung der Flyschbildungen der Alpen zwischen Reuss und Rhein. Eclogae geologicae Helvetiae 35(2), 247-291.

Lihou, J. 1995: A new look at the Blattengrat unit of eastern Switzerland: Early Tertiary foreland basin sediments from the South Helvetic realm. Eclogae geologicae Helvetiae 88(1), 91-114.

Lihou, J. 1996a: Structure and deformational history of the Infrahelvetic flysch units, Glarus Alps, eastern Switzerland. Eclogae geologicae Helvetiae 89(1), 439-460.

Lihou, J. 1996b: Stratigraphy and sedimentology of the Sardona unit, Glarus Alps: Upper Cretaceous/middle Eocene deep-marine flysch sediments from the Ultrahelvetic realm. Eclogae geologicae Helvetiae 89(2), 721 752.

Milnes, A.G., 1981: Sonderausstellung Sernftal. Katalog 2, Departement of Earth Science, ETH Zurich, Switzerland.

Milnes, A.G. \& Pfiffner, O.A. 1977: Structural development of the Infrahelvetic complex, eastern Switzerland. Eclogae geologicae Helvetiae 70(1), 83-95.

Oberholzer, J. 1933: Geologie der Glarner Alpen. Beiträge zur Geologischen Karte der Schweiz, Schweizerische Geologische Kommission, Bern, $626 \mathrm{pp}$.

Oberholzer, J. 1942: Geologische Karte des Kanton Glarus 1:50000. Spezialkarte Nr. 117, Unveränderter Nachdruck 1984, herausgegeben von der Schweizerischen Geologischen Kommission.

Passchier, C.W. \& Trouw, R.A.J. 2005: Microtectonics. Springer, Berlin, $366 \mathrm{pp}$.

Pfiffner, A.O. 1977:Tektonische Untersuchungen im Infrahelvetikum der Ostschweiz. Diss. ETH Nr. 5911, 432 pp.

Pfiffner, A.O. 1978: Der Falten- und Kleindeckenbau im Infrahelvetikum der Ostschweiz. Eclogae geologicae Helvetiae 71(1), 61-84.

Pfiffner, A.O. 1980: Strain analysis in folds (Infrahelvetic complex, Central Alps). Tectonophysics 61 (4), 337-362.

Pfiffner, A.O. 1986: Evolution of the north Alpine foreland basin in the Central Alps. In: Foreland Basins, Int. Assoc. Sediment. Spec. Publ., Volume 9 , 219-228.

Ramsay, J.G. 1967: Folding and fracturing of rocks. McGraw-Hill, New York, $568 \mathrm{pp}$.

Schmid, S.M. 1975: The Glarus overthrust: field evidence and mechanical model. Eclogae geologicae Helvetiae 68(2), 247-280.

Siegenthaler, C. 1974: Die nordhelvetische Flysch-Gruppe im Sernftal (Kt. Glarus), Unpublished PhD Thesis, University of Zurich, 83 pp.

Speksnijder A. 1987: the detection and significance of early deformation in the southern Variscian Pyrenees, Spain: implications for regional Palaeozoic structural evolution. Geol. Rundschau 76, 451-476.

Trümpy, R. 1969: Die Helvetischen Decken der Ostschweiz; Versuch einer palinspastischen Korrelation und Ansätze zu einer kinematischen Analyse. Eclogae geologicae Helvetiae 62(1), 105-142.

Wettstein, A. 1886: Ueber die Fischfauna des tertiaren Glarnerschiefers: Untersuchung aus der geologischen Sammlung in Zürich. Abhandlungen der Schweizerischen Paläontologischen Gesellschaft 13(2), 103 pp.

Manuscript received October 15, 2007

Revision accepted February 19, 2008

Published Online first July 25, 2008

Editorial Handling: S. Schmid \& S. Bucher 